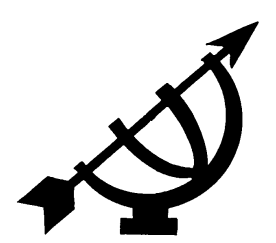

\title{
Moral-jural reflections on the right to marital dignity and the "nursery of human society": interpreting Luther's views on conjugal rights and benevolent love
}

\author{
A. Raath \\ Department of Constitutional Law \& Philosophy of Law \\ University of the Free State \\ BLOEMFONTEIN \\ E-mail: raathA.RD@mail.uovs.ac.za
}

\begin{abstract}
Moral-jural reflections on the right to marital dignity and the "nursery of human society": interpreting Luther's views on conjugal rights and benevolent love

At the advent of the Reformation, the institution of marriage, with particular emphasis on the marriage of priests and the degeneration of married life in Germany, proved to be a contentious matter in the discourse on marriage between Martin Luther and his colleague Melanchthon on the one hand and the papal authorities on the other. Although Luther subscribed to the basic definition of marriage postulated by the classical Roman jurists, he placed the issue of man's "de facto" conjugal union in a broader perspective of moral-jural right as the foundation of the spouses' duties and rights in marriage. Hence the distinction between "de facto" and "de jure" conjugal union enabled Luther and Melanchthon to develop a broader natural law-inspired view on marital dignity and the right thereto. In this article the origin, content and some implications of Luther's reformational perspectives on the dignity of marriage are investigated.
\end{abstract}




\section{Opsomming}

\section{Moreel-juridiese oorwegings van die reg op die waardigheid van die huwelik en die "kweekhuis van die menslike samelewing": 'n interpretasie van Luther se standpunte oor huweliksregte en welwillende liefde}

Met die aanvang van die Reformasie het die huweliksinstelling, met besondere verwysing na die huwelike van priesters en die verval van die huwelikslewe in Duitsland, 'n kontensieuse aangeleentheid geblyk te wees in die voortgaande diskoers tussen Luther en sy student Melanchthon aan die een kant en die pouslike owerhede aan die ander kant. Alhoewel Luther die basiese definisie van die huwelik volgens die klassiek-Romeinse juriste onderskryf het, het hy die "de facto" huwelikseenheid in 'n wyer perspektief van moreel-juridiese reg ingebed, synde die basis van die huweliksgenote se verpligtings en regte in die huwelik. Dus het die onderskeid tussen "de facto"- en "de jure"huwelikseenheid Luther en Melanchthon in staat gestel om 'n wyer natuurreg-geïnspireerde perspektief op die waardigheid van die huwelik te ontwikkel as wat tot op daardie stadium die geval was. In hierdie artikel word die oorsprong, inhoud en enkele implikasies van Luther se reformatoriese perspektiewe op die waardigheid van die huwelik ondersoek.

\section{Introduction}

At the advent of the Reformation, the institution of marriage, with particular reference to the marriage of priests and the degeneration of marital life in Germany, proved to be a contentious matter in the discourse between Martin Luther (and his student Melanchthon) on the one hand and the papal authorities on the other. Although Luther subscribed to the basic definition of marriage postulated by the classical Roman jurists, he placed the issue of man's de facto conjugal union in a broader perspective of moral-jural right as the foundation of the spouses' duties and rights in marriage. Hence, the distinction between de facto and de jure conjugal union enabled Luther and Melanchthon to develop a broader natural law-inspired view on marital dignity and the right thereto. For this purpose, Cicero's perspectives on moral duties provided Luther with a platform for integrating the Scriptural elements of marriage with the duties involved in the moral dignity of marriage. The de jure conjugal union between spouses means to have contracted to live in conformity with the duties of conjugal union. De facto conjugal union entails that spouses who have contracted de jure to conjugal society, are obligated to live in conformity to that society by practising conjugal benevolence aimed at attaining the supreme good. There- 
fore, although spouses who fall short of the depth of union proper to the institution of marriage, do not lose marital society de jure, through their fault conjugal union remains de facto unfulfilled; at the same time, spouses already married must, by practising benevolent love, strive to attain the supreme good through conjugal union.

\section{Luther and the Ciceronian perspectives on jural-moral dignity}

\subsection{Right and the moral imperative}

The legal contextualisation of the moral dimensions of justice, 1 fundamental rights and the foundation of laws, in Cicero's moral philosophy, arguably found its closest parallels in early modern times in the German Reformation of Luther and Melanchthon.2 Cicero's four-dimensional expression of justice as the foundation of all law (Fiat justitia, ruat coellum), jurisprudence as the science of justice, the closely-knit bond between right and morality and his definition of right (flowing from justice) served as connecting points in the early Reformation for Luther and Melanchthon to pursue the Biblical parallels of these foundational concepts, in dealing with issues concerning the order of creation.

Cicero's sensitivity to the moral context of law and politics appealed to Luther's and Melanchthon's rejection of legalism, moral relativism, the degrading of justice as the eminent good, and their statements of justice as the foundation of every human authority as well as that of every legislation arising from such authority. All rights ultimately emanate from the absolute source of moral good. This, according to Cicero, is the basic perspective in the philosophy of right. 3 This,

$1 \quad$ For Luther on justice, see Raath (2007a:335-354).

2 See Raath (2007c:1-32, at 4, 5, 14, 15, 18, 19; also note the remarks in Raath, 2007b:176-177):

Luther rejected philosophy in matters of faith, and he was afraid to acknowledge the philosophical insights of pagan thinkers like Cicero, disdaining to use the language of philosophy in order to communicate his message ... Luther's discourses on fundamental rights, however, show striking similarities to Cicero's arguments concerning duties, natural law, justice and the virtues binding together the individual citizens into a commonwealth subject to justice.

3 The philosophy of right (justice), to Cicero in his book, De Legibus ( $D L$ ), (The Laws), provides a far superior point of departure than starting with the positive laws of the state; note for example the discourse between Cicero and Pomponius in De Legibus $(D L), 1.4 .14$. where Cicero remarks on the un- 
however, does not exclude the right being embedded in human nature - right derives from human nature, and both have their origin in God himself. In his book on Laws, Cicero proceeds with his argument in favour of this view through four stages. Firstly, the supreme God generated man at a certain level of existence. 4 Although we see animals of all kinds and species, only man shares in reason and thought, qualities lacking in others $(D L, 1.7 .22) .5$ Having posed the question of what is more divine than reason, not only in human beings but in the whole of heaven and earth, Cicero answers that reason, when rendered complete and perfect, is rightly called wisdom. "There is nothing better than reason either in human beings or in God; humankind's first society with God is that of reason."6 Secondly, it is necessary that those who have reason in common should also have right reason - which is the law - in common. We must, therefore, recognise that human beings and God are "associated in law". And those who associate in law also associate in right, just as those who have these things in common must be considered as belonging to the same political order. 7 If human beings obey the same governments and the same powers, they should much more obey this heavenly order and divine mind and almighty God, which is reason. Thirdly, different from the animals, only man possesses any knowledge of God; among human beings there is no race so untamed and wild that it does not realise that there must be a God, even if they do not know which God should be

important details of the law, compared to the broader context of universal law. Note: unless otherwise stated, references to $L W$ are to Luther's Works (Luther, 1958-1967). The specific work of Luther referred to, is noted, e.g. Lectures on Genesis (LG), and the relevant Scriptural citation given where applicable. Abbreviations for Luther's particular works are explained in the bibliography. References to WA are to the standard edition of Luther's Werke (Kritische Gesamtausgabe - Weimar, 1883-1987).

$4 D L$ (1.7.22): "huc enim pertinet, animal hoc providum, sgax, multiplex, acutum, memor, plenum rationis et consilii, quem vocamus hominem, praeclara quadam condicione generatum esse a supremo deo ...".

5 "quid est autem non dicam in homine, sed in omni caelo atque terra ratione divinibus."

6 "quae cum addevit atque perfecta est, nominatur rite sapientia. est igitur, quoniam nihil et in deo, prima homini cum deo rationis societas; inter quos autem ratio, inter eodem etiam recta ratio communis est ...".

$7 \quad$ Keyes translates this extract as follows: "And since right reason is Law, we must believe that men have Law also in common with the gods. Further, those who share Law must also share Justice; and those who share these are to be regarded as members of the same commonwealth." ( $D L, 1.7 .23$. 
theirs. This shows that human beings, who alone know God, remember and as it were understand their genesis. ${ }^{8}$ Fourthly, man is able to recall, too, that virtue, which is the same for human beings and God, is not found in any other generation of things. Virtue is simply nature as perfect in itself and at its highest point. There is therefore a "likeness" between human beings and God. 9

The primary implication of Cicero's argument is that right is founded in human nature - this nature possessing reason, which Cicero understood as the trace of God and hence as the primary source, as well as the first subject of all rights. Rights, therefore, have a divine source, whilst ethics is concerned with duties, and natural right, with rights.

The second foundational jural-ethical dimension of Cicero's philosophy concerns the distinction between the philosophy of right and that positive right. In his book on Laws,10 Cicero, by mouth of Marcus in his dialogues with Pomponius, answers the question of Atticus as to whether the subject of right should be sought in praetorian edicts and the twelve Tables or in the depths of philosophy:

[l]n our discussion we should embrace the entire cause of universal rights and of laws in such a way that what we call civil right may be restricted within the small and narrow sphere of nature. We have to declare the nature of right, and seek it in the nature of human beings. We have to think about the laws which are suitable for governing communities, and then discuss the rights and statutes of civilised peoples in which the rights of our own people are included.

8 "ex quo vere vel agnatio nobis cum caelestibus vel genus stirps appellari postest. itaque ex tot generibus nullum est animal praeter hominem, quod habeat notitiam aliquam dei, ipsisque in hominibus nulla gens et neque tam mansueta neque tam fera, quae non, etiamsi ignoret quelem habere deum deceat, tamen habendum sciat. ex quo efficitur illud, ut is agnoscat deum, qui unde ortus sit quasi recordetur et agnoscat." (DL, 1.8.24-25.)

9 "lam vero virtus eadem in homine ac deo est neque alio ullo in genera praeterea; est autem virtus nihil aliud nisi perfecta et ad summum perducta natura; et igitur homini cum deo similitudo." (DL, 1.8.25.)

$D L$, Book 1. 
To Cicero, the philosophy of right 11 rejects as spurious and illegitimate sanctions which are not generated and contained virtually in the supreme source of all the supremely good things, inserted by divine providence in the human mind, which underlie the force of every right and the strength of every obligation. 12 This implies that whereas the science of natural right studies the principle of rights and from it deduces particular rights, some of which belong to human beings naturally, some of which are consequences of natural rights, the philosophy of positive right studies how positive laws should be made. In other words, political society, through its positive laws, has to protect true rights; it is not to invade natural freedom and thus violate rather than maintain the rights of individuals nor to create new, arbitrary and imaginary rights, nor to overlook any rights which could and should be carefully protected.13

In the third instance, Cicero draws into his theory of universal right the close bond between man and the objects he analyses in the epistemological sphere. Divine creation reflects God's providential plan with the universe as a cosmos of beings revealed to man in his quest for knowledge. The divine order of the world presents itself to us as an orderly system, which is not within our power to destroy, change or alter in accordance with what is useful or pleasurable to man. The order revealed to man carries a distinct moral character:

If we have learned anything at all about philosophy, we must have a firm, deep conviction that, even if we were able to hide what we do from all the gods and from all mankind, we should nevertheless abstain from all avarice, injustice, lust and intemperance. $(D O, 3.8$.

In addition to the dimension of universal justice, Cicero's argument also contains an element of social utility: for public right to achieve

11 To Cicero right exists only in virtue of duty which imposes another human being's respect for that which constitutes the matter of right. Although natural right deals with rights alone, it also deals with duties in other human beings, therefore, something becomes right in virtue of this relationship with such duties.

12 "Quid sit homini trbutum natura, quantum vim rerum optimarum mens humana contineat."

13 The first duty of the philosophy of positive right is to consider the laws of the state, confronting them with the ideal laws which it has formulated in order to test the civil laws and see if they are justly directed to the protection of true rights. Ideally speaking, the laws of the state have to protect true rights exactly, neither more nor less; they are not to invade natural freedoms. 
justice, public utility should be universalised - utility should be the same for all. If anyone should appropriate utility to himself, all human association would be terminated: "Even if nature prescribes that one human being provide for another, whoever he may be, it is still necessary, according to nature itself, that the utility of all be common, precisely because other persons are human beings." (DO, 3.2.) This implies that, for justice to be done, the human being as person should be considered within the universal context of morality common to the whole of humanity. Although directed at others, universalising utility means also reaping the fruits thereof by oneself. In essence it entails that virtuous utility takes its root and origin from more profound principles of morality. ${ }^{14}$

Combining the principles of universal right revealed to man and the universalising of utility within the context of morals demands an eudemological dimension - the final goal for which right and utility exist. Cicero finds this in the precept that we should love other human beings as ourselves because our natures are equal.15 Here nature has an objective sense, reaching out to the true moral principle of the practical acknowledgement of the nature of beings. Cicero incorporates within his argument for combining justice and utility, man's common longing for benevolence. In his De Legibus, he observes that if this were the case with nature, so too in their judgement "right" would be cultivated by all. Some people may find it incredible that a wise man bestows extensive benevolence upon another endowed with equal virtue. Nevertheless, this act is necessary if he is to love another no less than himself. 16 Through benevolence, justice and utility are combined into virtue and the attainment of the ultimate good. Transposed into jural terms, Cicero's observations amount to the fact that right is fundamentally a faculty which human beings have for doing or experiencing anything useful, protected by a more basic (or fundamental) moral law which obliges others to respect this faculty. This faculty for doing or experiencing

14 The Kantian Categorical Imperative reflects an effort to fuse utility with universal conceptions of natural right.

15 See $D L$ (1.12.35): "From this it is clear that, when a wise man shows toward another endowed with equal virtue the kind of benevolence which is so widely diffused among man, that will then have come to pass which, unbelievable as it seems to some, is after all the inevitable result - namely, that he loves himself no whit more than he loves another. For what difference can there be among things which are all equal?" 
anything useful to human beings is an eudemological good, which means that properly speaking rights pertain properly speaking to eudemology. 17

\title{
2.2 The moral imperative, being and moral obligation
}

Luther quotes on numerous occasions from Cicero's well-known remark that the height of right is the height of wrong 18 - if the application of justice is not accompanied by equity and fairness, the effects of strict law may be highly unjust (DO, 1.10.33; $L W, 3$ (LG), Genesis 19:10; LW, 4 (LG), Genesis 21:33).19 Furthermore Luther subscribes to certain rights that are inborn and present in the order of creation, similar to Cicero's views, for example that the law of selfdefence is a natural right and the principle that to each man belongs his own20 (LW 25 (LR), Romans 2:15; LW, 36 (W\&S (II), SBBC).

It was, however, the core of Cicero's teaching on person and morality that appealed most to Luther's engaging with morals in the order of creation: morality imbues human actions with the force of obligation. Luther transposed Cicero's appeal to benevolence as the moral imperative obligating human action, into the twofold demand

\begin{abstract}
By nature and indelibly the law of nature is imprinted on their minds, while their conscience bears witness to them. This implies that the conscience of any person (so long as it does not err or is not dulled by too much neglect) stings and murmurs when a person has done evil. But it quiets down when he has done good. Therefore also Cicero could say: 'The consciousness of a wellspent life is a most pleasant remembrance.' Thus it is proved on the other hand from the considerations that they know what one must do and what one must not do, that is, they know the Law.
\end{abstract}

18 Luther was fond of quoting the maxim "Summum ius, summa iniuria" (sometimes cited as "summua iniustitia") from Cicero's De Officiis (DO, 1.10.33). In his famous treatise On Secular Authority (1523), Luther describes how the ruler should fear God; show love for his subjects; keeping his eye on the example of Christ; be cautious of human counsellors; and practise equity (epeikeia, Billigkeit), fairness, cf. Aristotle $(1926,5.10)$ and moderation towards evildoers. Also see LW (3 (LG), Genesis 19:10; 4 (LG), Genesis 21:33; 15 (ESL\&S), Ecclesiastes 7:16; 34:130 (TF\&L); 46:124 (SBS).

Also note LW (15 (Ecclesiastes 7:16, The highest law brings the deepest injustice; 46:124 (SBS), The strictest law is the greatest injustice; 34:130 (TF\&L), The loftiest right is the greatest injustice; 54:325 (TT), recorded by Anthony Lauterbach, The strictest right is the greatest wrong).

20 The shorter sermon copy here quotes in Latin the Bornan civil law: "unicuique tribuendum suum ius" (LW, 36:357 (SBBC)). 
of Scripture to love God and our neighbour. Man's enlightened reason provides virtuous moral judgements. Through God's divine Spirit, man knows and understands God's being and the being of others. The moral imperative of love (benevolence) is not concerned with reason in the first place, but with the light of reason (right reason). The light of reason is objective and immune from error, whilst reason, a subjective activity, can and does err. Cicero's major contribution to Western legal philosophy consists in establishing a close link between "right reason" and the moral imperative of benevolence. In Luther and Melanchthon's thought it provided a foundation for establishing the view that human beings begin their existence rooted in morality and in moral obligation flowing from the moral law, which is common to all individuals irrespective of race, sex, nation, culture or religion; it binds everyone without exception. Acknowledging, like Cicero, that the whole of mankind is subject to the limitations and mutability of human personhood, Luther maintains that the immutability of the moral law furnishes morality with its undeniable sense of obligation.

In the order of creation, the necessity and immutability of the idea of being, 21 together with the undeniable sense of obligation appeal to man to shun human autonomy or theories propagating dispensationalist views or advancing the idea of the mutability of the moral law. In the order of creation, the obligating moral law brings man to acknowledge the innate dignity conferred on human beings by their very existence as human persons, as an absolute inviolable right, and the Absolute Source of all moral obligations which confers on man the light of being. Moral good in the order of creation, together with human being attached to creational being and Absolute Being, comes through recognising (and honouring) other persons and God for what they are.

\subsection{Justice, human dignity and the moral imperative}

In order to appreciate the implications of right as the basis of all human rights, the relationships that exist between human beings as such need to be examined. These relationships are constituted by duties and rights, which are attached to the moral imperative in order to be understood. This needs an appreciation of the moraljural bonds of human existence, and culminates in an understanding

21 Luther's views on "being" are perhaps the most neglected aspects of his theology. 
of the moral law that provides law with its moral context, and law providing morality with its social form.

Justice is the root and essence of all morality; it is expressive of right as the activity of the person exercising it in harmony with and protected by the moral law itself. In other terms: right is a faculty to act freely, protected by the moral law, which demands respect from others for this faculty. This definition implies that in the order of creation, the individual's obligation to be just ensures for him the right to act within the limits of justice. His duty to act in accordance with justice imposes on others the duty to respect this obligation. Duty and right, therefore, form a correlative unity in the sense that there can be no right in one person without a corresponding duty in others to respect that right. My duty, for example, to worship God, gives rise to my right to worship God; a right which others have a duty to respect. Furthermore, the concept of duty is anterior to that of right and as such does not necessarily give rise to rights in others. For example, my duty to worship God does not necessarily imply that others' rights are violated if I do not worship God, as I should.

\subsection{Marriage, social right and conjugal union}

Apart from ecclesiastical and political society, Luther distinguishes conjugal society as a third estate in the order of creation. ${ }^{22}$ In conjugal society, every good possessed by human beings is put in common; including the spiritual goods of truth, virtue and happiness, as well as the complementary good that man and woman can offer one another for their mutual enjoyment as a result of their psychological and somatic differences. In this union persons of different sex form the essence of conjugal society. Husband and wife are two human beings who unite in the fullest way possible as man and woman, according to enlightened reason.

22 For marriage and the household as a third estate, see LW (15:338 (ESL\&S), Ecclesiastes 1:1, Preface of Doctor Martin Luther; 35:388 (W\&S (I), PNT); 39: Introduction (C\&M (I)); L 41:301 (C\&M (III), ARP)); 51:335 (S (I), SML); cf. also LW, 37:364 (CCCS). Wilhelm Maurer comments as follows on the origin of Luther's three-estates theory: "Luthers Dreiständenlehre ist aus seinen katechetischen Bermühungen erwachsen. Sie liegen vom Anfang seiner öffentlichen Wittenberger Tätigkeit an vor und erreichen 1529 in der Abfassung der Katechismen ihrer Höhepunkt. Sie beleiten dauernd seine Predigt, auch in seinen exegetischen Vorlesungen brechen sie immer wieder durch." (Maurer, 1970:18.) 
Sexual union, exercised as a right, constitutes the special aspect of marriage. To Luther, the marriage union entails

- exclusive love between the spouses;

- monogamy;

- the indissolubility of marriage; and

- the need to hold everything in common. The marital union presupposes and requires for the sexual union, every other union between man and woman. Therefore, marriage cannot be merely a physical union, but must find its ultimate end in the spiritual domain.

\section{The dignity of marriage}

\subsection{Marital dignity concerning the conjugal union as such in the order of created being}

\subsubsection{Marital dignity as the common value of constitutive sexual union between spouses}

- Marital dignity as the value of sexual propagation

The Lutheran sexual ethic takes its root in God's promulgation of the law of marriage by drawing the woman from the side of the sleeping Adam, thereby expressing the relationship between man and woman. God promulgated the conjugal law by the fact of the production of woman from Adam's rib and Adam confirmed it with the words which interpret the divine creation of the woman. The "law" of the two sexes was thus shown to be founded in the reality of things, in the nature of man and woman, and in their mutual appropriateness, which drew them to their perpetual, full union as conjugal partners. As a consequence a number of duties and accompanying rights concerning the conjugal union as such surface in Luther's sexual ethic. 23

$23 L W(5$ [LG] Genesis 28:2, Marriage is primarily a matter of morals - it deals with the dignity of marriage; 11 (FLP(II)), Psalm 119:145, The cry of the heart in a moral sense is an intense longing for righteousness, truth and salvation; over and against this elevated view of marriage, there is the foolish view which regards the state of matrimony as a superfluous, presumptuous human thing that one could dispense with and do without just as I can do without an extra jacket or coat; 9 (LD) Deuteronomy 22:1, Honourable marriage benefits a wellordered commonwealth). 
In his comments on Genesis 1:26-28 Luther describes God's creation of the two sexes as a natural institution and as a divine ordinance. The love of one sex for the other is a natural law, which cannot be suspended without an "extraordinary work" of God ( $L W$, (BC, CELC), Art. 23). ${ }^{24}$ God created man and woman differently not for lewdness but to be true to each other, to be fruitful, beget children, and to support and bring them up to the glory of God ( $L W$, (BC, CELC), The Sixth Commandment). ${ }^{25}$ Commenting on Matthew 19:6 ("This is why a man must leave father and mother, and cling to his wife, and the two become one body"), Luther also finds the same principle in the New Testament - the joining together of a man and a woman is a divine ordinance and institution ( $L W, 1$ (LG), Genesis 2:23). The Bible, therefore, reflects the highest praise for sex in that the male is the father in procreation and the female the mother ( $L W$, 1 (LG), Genesis 2:18). 26 Even after the fall of mankind, God in his providence, provided marriage as a remedy for lust and permits sexual intercourse, blessing the union of male and female ( $L W, 3$ (LG), Genesis 16:4).27 In the order of creation God's creation of man and woman reflects an element of "complementary being" of the two sexes: "God created man ... Male and female He created them" (Gen. 2:17-18). From this passage we may be assured that God divided mankind into two classes, namely male and female, or a he and a she. ${ }^{28}$ This was so pleasing to Him that He Himself

24 For this reason marriage is a "natural" institution, see WA $(\mathrm{Br}), 8$ (1537-1539), No. 3423, Luther \& Melanchthon - Philipp von Hessen: "Gott hatt die ehe also eingesatzt, das es allein zweier person gesellschaft sein sollt, und nicht mehr, so die natur nicht verderbet were, Das will der spruch: Es sollen zwey jn einem fleisch sein ...".

25 Luther also comments:

$\mathrm{He}$ (God) sanctioned it above in the fourth commandment, 'You shall honour father and mother'; but here, as I said, he has secured it and protected it. Therefore he also wishes us to honour, maintain, and cherish it as a divine and blessed estate. Significantly he established it as the first of all institutions, and he created man and wife differently (as is evident) not for lewdness but to be true to each other ...

26 Luther adds: "When we look back to the state of innocence, procreation, too, was better, more delightful, and more sacred in countless ways."

27 See $L W,(B C, C E L C)$; Article XV: Human traditions in church; AAC (1531), 1.8.2.6, Because of the temptation to immorality each man should have his own wife and each wife her own husband.

28 In LW (3 (LG), Genesis 17:1), Luther explicitly states that Adam was joined in marriage with Eve by God's ordinance. 
called it a good creation (Gen. 1:31). Therefore, each one of us must have the kind of body God has created for us. I cannot make myself a woman, nor can you make yourself a man: "we do not have that power" (LW, 45:387 (CIS (II), PCM)). If, therefore, someone takes a marriage partner who is unfit for marriage in the sight of God, there is no real marriage between them - marriage partners must be sexually equipped for marriage (cf. $L W, 45: 19$ \& 28 (CIS (II), EM)).

Because the joining together of man and woman in marriage is a natural thing, the definitions of the canonists, theologians and lawyers reflect the requirement of spouses of different sex as a constitutive element of lawful marriage (cf. $L W, 45$ (CIS (II), EM), Genesis 24:5). Because of the sexual bond instituted by God, He does not wish to have the marital institution forbidden and despised29 (cf. $L W, 34: 41$ (CR (IV), EGA) ${ }^{30}$ ). Marriage is a weighty matter in the sight of God (LW, 44 (CIS (II), SEM)). God made man and woman so that they can come together in order to multiply ( $L W, 45: 17$ (CIS (II), EM)). Except for eunuchs, "let no man presume to be without a spouse" (LW, 45 (CIS (II), EM)). All should thank God for creating them man or wife - no sex is to be despised in the face of God ( $L W$, 45:17 (CIS (II), EM)). ${ }^{31}$

Luther defends the value of marriage against efforts by the church to degrade its value, e.g. WA (TR) 4, Sammlungen Khumers, Mathesius u.a. (1538-1543).

\begin{abstract}
You hear that it is an anti-Christian outrage and plague to despise the love of women, that is, to forbid marriage. For God has created women to be held in honour and as helpers for man and for this reason he does not wish to have such love forbidden and despised. The flesh and the devil teach men to use women only for dishonour so that one after another is put to shame ... That is not to love women, but to love and seek unchastity and shame in women, treating and regarding them not as women but as harlots, so that henceforth no one wants to love or respect them. But God wills that they be valued and esteemed as women and that this be done gladly and with love. That is to say, one should take them in marriage and remain with them in conjugal love. That pleases God ...
\end{abstract}

31 For Luther's emphasis on sexual propagation as an ordinance of God, see $L W$, (BC, CELC) XXVII: Monastic Vows, CF (1530), 3.6.20, God created man and woman differently not for lewdness, but to be true to each other, to be fruitful, to beget children, and to support and bring them up to the glory of God; 1 (LG), Genesis 2:22, Matthew 19:6, What God has joined together let no man put asunder; for the lawful joining of a man and a woman is a divine ordinance and institution; 3 (LG), Genesis 16:4, God blesses marriage, it is the inseparable union of male and female; 45:19 (CIS (II), EM), If a marriage partner has a spouse who is unfit for marriage, in the sight of God there is no real marriage between them). 


\section{- Marital dignity as the value of full sexual union}

Accidental variations in our bodies do not depend on us, but on nature itself. Mankind lacks an immutable, uniform condition. Although all human beings have a similar design and nature, there are among human beings many accidental variations and differences in sex, temperament, and so forth. These variations do not reduce the intimacy of the conjugal union among human beings. If the differences among human beings were contrary to nature, such variations would be harmful to others and would reduce the closeness of the union among people. In Luther's marital ethic, it stands paramount that divine providence unites human beings by the variety of their gifts so that they are mutually helpful or necessary to each other. The sexual differences between men and woman function as natural variations to ensure the fullness of sexual union between spouses. The physico-moral differences between men and women are directional and necessary for ensuring the complementary nature of conjugal union. The union between man and woman is necessary, for God has created women to be held in honour and as helpers for men ( $L W, 34: 17$ (CR (IV), EGA)). A woman is created to be a companionable helpmeet, in particular to bear children. The fullness of conjugal union finds expression in a particular form of married love ( $L W, 44: 7$ (CIS (I,) SEM)). Married love, distinguished from false love and natural love, is the highest expression of conjugal love; it represents the closest form of unifying benevolent love because the fullness of conjugal union demands man and woman to give themselves fully to one another (LW, 44:7 (CIS (I), SEM)). This is the reason why men sometimes define marriage as the union or companionship of man and woman ( $L W, 5$ (LG), Genesis 28:2). Benevolent conjugal love in marriage commits man and woman to serve one another ( $L W, 5(L G))$.

The fullness of marital union in Luther's sexual ethic produces important consequences. Aroused affection between partners of the same sex binds the human will to earthly and sinful pleasure, and despises God's creative and providential government of marital relations. Sensuous affections and physical love between persons of the same sex is disordered and wrong, and it is also disordered and wrong between persons of opposite sex, unless they are bound or bind themselves by legitimate marriage. Every sexual movement or aspiration that does not have generative union between spouses as its immediate end is an opprobrious disorder, contrary to nature and the Creator's will, and it is reproved by human and divine law. For the morally virtuous human being there are no sexual pleasures outside marriage and sexual pleasures between persons of the 
same sex (which a morally virtuous person will never want) are a necessary consequence of the sexual tendency whose legitimate mode of satisfaction is, however, in honest marriage. 32

\subsubsection{Marital dignity as the value of preserving and realising conjugal union}

\section{- Marital dignity as the value of indissolubility}

The fullness of conjugal union gives rise to rights and duties held in common by both conjugal partners. The moral imperative demands that the duties and rights concerning conjugal union as such be respected and maintained. The first fundamental duty and its accompanying right, is the duty of the indissolubility of marriage. Marriage, says Luther, is the inseparable union of male and female. (LW, 3 (LG), Genesis 16:4). Although not all definitions quoted by Luther refer to God as the final end of marriage, there was general agreement in his day among the canonists, civil lawyers and the theologians that marriage implies inseparable companionship ( $L W, 4$ (LG), Genesis 24:4; 5 (LG), Genesis 34:9); also, Moses says that a wife should be an inseparable companion for life in the eyes of her husband (LW, 5 (LG), Genesis 29:20). 33

\section{- Marital dignity as the value of unicity (uniqueness)}

The fullness of conjugal union is only attainable if the marriage state consists between one man and one woman. 34 Such union would not

Luther points out the moral evils resulting from the degeneration of marriage and the broad spectrum of other evils that may follow in its wake (WA $(\mathrm{Br}) 8$ $(1537-1539))$. He adds that those who despise marriage will not enter God's Kingdom.

33 The marriage vow, to Luther, is constitutive to the marriage union ( $L W, 44: 10$ (CIS (I), SEM)), It is indissoluble because marriage is a covenant of fidelity; man and woman surrender themselves to one another; 1 (LG), Genesis 2:23, The affecting cause of marriage is God, but the final cause is for the wife to be a "dwelling place" to her husband. (On the indissolubility of marriage see $L W, 3$ (LG), Genesis 16:4, "marriage is the inseparable union of male and female"; and the theological definition cited by Luther (LW, 4 (LG), Genesis 24:4; 5 (LG) Genesis 28:2; 1 (LG), Genesis 2:22, "What God has joined together let no man put asunder" (Matt. 19:6); 5 (LG) Genesis 29:8; LW, 21 (SMM), Matthew 5:33.)

34 Luther's statements of the value of unity in marriage are to be found from his earliest works to the latest ( $L W, 44: 10$ (CIS (I) SEM), It is the union of one man and one woman, barring the way to the body of anyone else; $L W,(B C, C E L C)$ ), The Sixth Commandment, LC (1529), 1, 201, God prohibits promiscuity and unchecked lust as was evidenced in Sodom and Gomorrah; LW, (BC, CELC), The Sixth Commandment, LC, 1, 201, LW, (BC, CELC), Introduction to SC 
be full if the woman did not give herself totally and exclusively to the man nor if the man did not give himself totally and exclusively to the woman, but each had much carnal affection. It is the will of the Creator that marriage partners abstain from immorality 35 ( $L W$, 51:355, (S (I), SML)). 36 The uniqueness of man and woman respectively, also demands that spouses do not criticise the opposite sex ( $L W, 5$ (LG), Genesis 2:22). Addressing the men in particular, Luther admonishes that some may find fault with the opposite sex and have nothing to do with marriage. Through their baseness and wickedness these people lay waste on God's building "and they are really abominable monsters of nature". Therefore men have to obey the Word of God and recognise their wives as a building of God ( $L W, 5$ (LG), Genesis 2:22). ${ }^{37}$ Luther also points out that it is most honourable to live with one's lawful spouse and to avoid fornication ( $L W, 4$ (LG), Genesis 24:4). ${ }^{38}$ One should oust the sensual desires with all

(1529); LW, 2 (LC), Genesis 14:16; LW, 2 (LG), Genesis 6:2; LW, 2 (LG), Genesis $6: 2$, The world shuns the legitimate and divinely instituted union of the male and the female; LW, 28 (C\&T), 1 Corinthians 7:1, Those who have committed themselves to fornication and not tying themselves to the labour of married life; the Spirit says: "He is wise who takes a wife"; $L W,(B C, C E L C)$, Introduction to SC (1529), The destruction of Sodom and Gomorrah is the direct result of their promiscuity; $L W,(B C, C E L C)$, The Sixth Commandment, LC (1529), 1, 201, God prohibits lust and promiscuity; LW, 2 (LG), Genesis 6:2, The contempt of God and his Word leads to injustice, tyranny and lusts; $L W, 5$ (LG), Genesis 29:12, Marriage is a godly thing; a natural desire and inclination of sex to sex).

35 Luther often cites the example of Sodom (WA (Br), 12:187, No. 4259, Luther Melanchthon, Wittenberg 1535: "On the indissolubility of marriage", see $L W, 3$ (LG), Genesis 16:4: "marriage is the inseparable union of male and female"; and the theological definition quoted by Luther $L W, 4$ (LG), Genesis 24:4; LW, 5 (LG), Genesis 28:2; $L W, 1$ (LG), Genesis 2:22: "What God has joined together let no man put asunder" (Matthew 19:60; LW, 5 [LG], Genesis 29:8).

36 Luther has in mind the text from Hebrews 13:4: "Let marriage be held in honour among all, and let the marriage bed be undefiled; for God will judge the immoral and adulterous."

37 Luther probably has in mind here texts alluding to the terrible sins of Sodom and Gomorrah, which drew God's wrath. (See e.g. WA, (DB), Der prophet Jesaia (Heidelberger Handschrift, 1572/1528) 1:10: "Horet (zu yhr furrsten) des HERRN wort / yhr fursten von Sodom / nym zu ohren unsers Gottes gesetz / du volck von Gomorra" and 3:9: "Denn sie sagen von yhren sunde / wie Die zu Sodom und verbergen sie nicht / Wehe yhrer seelen / Denn est ist yhr mit bosem vergolten.")

38 To live virtuously, to Luther, is a recurrent theme in his marriage ethic ( $L W$, 45:42 (CIS (II), EM), It is no slight boon that in wedlock fornication and unchastity are checked and eliminated. This in itself is so great a good that it alone should be enough to induce men to marry forthwith; LW, 45:41 (CIS (II), 
zeal, repress and detest concupiscence and strive after modesty and chastity ( $L W, 4$ (LG), Genesis 24:4). Marriage is sacred, and a divine institution; it is not disgraceful or dishonourable, but it has been dishonoured by lust ( $L W, 5$ (LG), Genesis 29:26).

\section{- Marital dignity as the value of cohabitation}

Full conjugal union, apart from indissolubility and unicity, also needs cohabitation to accomplish its divine purpose. There must be a mutual, continual concern of man and woman to lighten the other's hardships, to support one another because, according to Scripture (Gen. 2:24), a man shall leave father and mother, and shall cleave to his wife, "and they shall be two in one flesh" (see Ps. 44:11). The forceful division of man and wife wrongly attempts to deprive their sexual union of its necessary dignity. Such a division sins against marital spouses by preventing the fulfilment of their moral duty of cohabitation and reciprocal help; it violates the law of God. The absence of cohabitation destroys the benefits of children, trust and the sacramental nature of marriage ( $L W, 2$ (LG), Genesis 12:13). 39 Neither can love flower ( $L W, 54: 222$ (TT), recorded by Anthony Lauterbach and Jerome Weller), or the necessary companionship be furthered (LW, 44:3, (SEM)). 40 God instituted marriage for husband

EM), Marriage comprises noble virtues and true delights; $L W, 1$ (LG), Genesis $5: 32 ; L W, 1$ (LG), Genesis 2:22, Marriage is, in a certain sense, the primary battlefield between God and Satan - God wants marriage to be a remedy for depraved nature, and Satan and the enemies of Christ have denied that there is any chastity in marriage; $L W, 44: 154$ (CIS (I), CNGN), Where virtue ceases dishonour and shame are made to look like honour and glory; theft or robbery is legalised; every kind of impurity and evil is knighted or raised to nobility; marriage is permitted which is within the prohibited relationships or otherwise forbidden ... "Here the devil becomes a saint", LW, 40:273 (C\&M (II), IPP), Every estate should remain and be held in honour, and faith should exercise itself peacefully in love (Gal. 5:6); LW, 40:361 (C\&M (II), TK), The origin of marriage is closely attached to faith, love and all virtues; also see $L W, 40: 298$ (C\&M (II), IPP); LW, 41:122 (C\&M (III), CC).

39 "Augustine learnedly enumerates three benefits in marriage: trust, children and its sacramental character. And truly, if there is no trust, hearts will never unite closely; nor will there ever be any true love between them. But this world has nothing more beautiful than this union of hearts between spouses."

40 In this brief sermon Luther speaks of marriage as God's gracious gift to man and woman. It is God who gives a man and a woman to each other; therefore, those who wish to marry should seek God's guidance in finding a spouse. Marriage, then, is far more than mating; it is a covenant of physical and spiritual fidelity for life (SEM (1519); WA (S), 2, (162) 166-171). 
and wife to live together ( $L W, 28$ (C\&T), 1 Corinthians 15:25). $41 \mathrm{God}$ commands those married to maintain the conjugal rights $(L W, 28$ (C\&T), 1 Corinthians 7:7). It is God's ordinance that husband and wife live together ( $L W, 22$ (SJ (I)), John 1:17).

\section{- Marital dignity as the value of community of goods}

Conjugal love unites marriage partners not only in physical union, but also in community of property. In marital union "the wife shines by reason of her husband's rays". Whatever the husband has, the wife also has and possesses in its entirety. The result is that the husband differs from the wife in no other respect than in sex; otherwise the woman is altogether a man. Whatever the man has in the home and is, this the woman has and also is ( $L W$, no. 3 (LG), Genesis 2:24). This close union of bride and bridegroom Luther also applies to the church - the bridegroom (Christ) and the bride (the church) are joined in the same spirit, and everything they have becomes common property ( $L W, 8$ (LG), Genesis 49:13). The supreme love of the bridegroom for his bride brings with it one faith, one body, and one mind. Whereas the relation between Christ and the church is real, in physical marriage we only find images and representations of spiritual marriage. When man and woman are joined together in physical marriage, one body is formed, the goods are in common, and everything else are "common property". The wife is just as much mistress over the goods of her husband as the husband himself, and in nothing is she differentiated from her husband, except that the husband is lord of the wife ( $L W, 12$ (SP (I)), Psalm 45:10).

In marriage the spouses become one in the flesh and the wife shares in the name and property of the husband (LW, 17 (LMP), Isaiah 65:4). The binding together of spouses in marriage is accomplished through conjugal love: there is on earth no love more ardent than that between a groom and his betrothed. The groom gives his bride not a gift but himself, the deepest love of his heart and all his property (Hos. 2:19; LW, 18 (LMP (I)), Hosea 1:2). The coming together of man and wife in marriage brings with it that the woman is no longer merely a woman, she is her husband's help-

41 "Every purpose for which God instituted marriage, namely, that husband and wife live together and beget children and then rule city and country and people ...". This presupposes concord in the marital union ( $L W, 3$ (LG), Genesis 16:6, We must trust in God and, as much as is possible, preserve harmony - since we must live among ungrateful and wicked people, no place will fail to present occasions for discord and trouble; $L W, 2$ (LG), Genesis 6:3, God commands the husbands to love their wives). 
mate, who possesses her husband's property and body ( $L W, 22$ (SJ (I)), John 3:31).

To Luther, good things in marriage include offspring and community of property ( $L W, 54$ (TT), recorded by John Schlagenhaufen). 42 Not only physical things, but also the spiritual benefits of marriage are made common property by love ( $L W, 25$ (LR) Romans 12:14 ff.).

\subsection{Marital dignity pertaining to the functioning of the conjugal union in the order of creation}

\subsubsection{Marital dignity as the value proper to sexual union 43}

\section{- Marital dignity as the value of common moral perfection (common benevolent love)}

Differences in characteristics, gifts which distinguish the human male and female, make sex important and provide a special character to the mode of exercising them. The duties and reciprocal rights attached to the exercise of sexual union in the conjugal bond are manifold: the right and duty to render conjugal debt, the right and duty to carry out sexual union befitting human nature, the right and duty to respect the conceived foetus, and the right and duty of raising and educating the offspring.

\section{- Marital dignity as the value of rendering the conjugal debts}

Marital partners have the duty not to deprive each other of conjugal debts, except by agreement, because by the marriage vow each submits his body to the other in conjugal duty. When one resists the other and refuses the conjugal duty, he/she is robbing the other of the body he/she had bestowed upon the other. This is contrary to marriage and dissolves the marriage (LW, 45:34 (CIS (II), EM))44; $L W, 45: 32$ (CIS (II), EM)). The rule of love demands that in the estate of marriage no one rules over his own body, but must serve his spouse, as is the way of love. Such is not the way of fornication,

42 Also note Luther's remarks (LW, 54 (TT), No. 185 (1532): "Marriage consists of these things: the natural desire of sex, the bringing to life of offspring, and life together with mutual fidelity.").

43 This includes the values of enhancing mutual esteem and affection, of enhancing the harmonious life of marriage partners and the value of preserving concord.

44 Where a man loves his wife, thinks of her as his wife and touches her as his wife, no one can commit adultery ( $L W, 28$ (C\&T), 1 Corinthians 7:2). 
where no one rules over the other or owes his partner anything, rather each seeks only his own in the other. Therefore it is against the law of love and also against God. Truly it is a profound saying that no one rules over his own body, that where fornication tempts, one should be subservient to the other and should give himself to no other. Thus we see that adultery is the greatest thievery and robbery on earth, for it gives away the living body, which is not ours, and takes another living body, which is also not ours; "the bride is the bridegroom's and not the ruler over her own body, and furthermore one shall let the matter rest there and not try to do everything better" (LW, 28 (C\&T), 1 Corinthians 7:4).45 Luther explains, regarding mutual duties and rights in conjugal union, that St. Paul instructs married people in their conduct towards one another with respect to marital duty and speaks of "conjugal rights". It is a right, yet it should occur voluntarily. This right arises from God's permission of the marriage state and his forgiveness of what He otherwise punishes and condemns. Thus the state of matrimony is constituted in the law of love so that no one rules over his own body but must serve his partner, "as is the way of love" (LW, 28 (C\&T), 1 Corinthians 7:4). In total the conjugal obligation is not reprehensible within marriage, but in all other cases outside the bond of marriage, it is a mortal sin $(L W, 44: 10$ (CIS (I), SEM)).46

45 Luther offers this as criticism against efforts to make laws separating the bride and bridegroom until the third night of marriage ( $L W, 28$ (C\&T), 1 Corinthians $7: 2)$.

46 Luther's call to render conjugal debts surfaces in many of his works ( $L W, 46: 309$ (CIS (III), OMM), Christian freedom is not given to anyone to be used for his own pleasure and caprice or to the harm, injury and vexation of others, but only for the need and danger of the conscience, so that each may serve the other and benefit him; $L W, 28$ (C\&T), 1 Corinthians 7:4, Conjugal debts flow from conjugal love - the right arises out of God's permission of the marriage state, for thus the state of matrimony is constituted, the law of love, so that no one rules over his own body but serves his partner as is the way of love. Such is not the way of fornication, where none rules over the other or owes his partner anything, therefore it is against the law of love and also against God; $L W, 28$ (C\&T), 1 Corinthians 7:4, St. Paul would rather see prayer and fasting be relaxed than that one should so rule his body as to deny it to the marriage partner; LW, 45:34 (CIS (II), EM), The marriage vow binds and compels spouses to submit their bodies to one another in conjugal duty; when one resists the other the conjugal duty he/she is robbing the other of the body he/she had bestowed upon the other. This is really contrary to marriage, and dissolves the marriage); see also $L W, 45: 32$ (CIS (II), EM). 


\section{- Marital dignity as the value of carrying out sexual union befitting human nature}

Enlightened human reason is aware of the respectability which exists in the lawful union of man and woman. In the second place it appreciates the enormous advantages which flow from this source: law, states and households, which would necessarily collapse and perish if there were no lawful, chaste and secure marriages ( $L W, 3$ (LG), Genesis 16:7; LW, 3 (LG), Genesis 16:7). Reason also teaches the heathen to approve of marriage and to compel their youth to marry ( $L W, 4$ (LG), Genesis 24:5; $L W, 4$ (LG), Genesis 24:5). The value of chastity in marriage is taught by God to Christian and heathen, because "God is not only the God of the Jews but also the God of the Gentiles" (LW, 6 (LG), Genesis 34:23; LW, 7 (LG), Genesis 41:46). God has no pleasure in an immoral, heathen life which cannot bring forth virtues of faith, love and chastity ( $L W$, 40:301 (C\&M (II), IPP)).

Luther's reflections on marriage deal extensively with God's anger at sexual vices. All sexual relations and practices contrary to human nature draw the anger of God. The destruction of the flood and the punishment of Sodom and Gomorrah reveal God's wrath at human vice $(L W,(B C, C E L C))$. The Sodomites and their neighbours were very wicked men, therefore God visited them with war, "and the wrath of God rested heavily on them" (LW, 2 (LG), Genesis 14:16). 47 Contempt of God and his Word leads to injustice, tyranny and lusts - every sort of trouble has its origin in lust. Where the Word is not present or is disregarded, men cannot avoid falling into lusts. Lust brings with it countless other evils and injustices ( $L W, 2$ (LG), Genesis 6:3). Sexual sins involve forsaking God, therefore it is not the integrity of sex and the dignity of marriage which are

47 To Melanchthon, Luther wrote (WA (Br) 12:187 No. 4259, Wittenberg, 1535): "Denn da Sodom lange hatte gar schwerlich gesundigt und Gotte erzürnet, und da sie itzt solt unter gehen und zeit war, das sie büssen und sich bessern sollt, da wird sie aller erst erger und so sicher, das sie auch Gotte trotzete und jn verlachtte, flugs des selben morgens war sie dahin, jnn abgrund verschlungen." Elsewhere he continually expresses his disgust at unnatural sexual practices: LW, 46:198 (CIS (III), WAT), Human beings should not think lightly of marriage, like the practices of Sodomy in Turkey and see $L W, 34: 43$ (CR (IV), EGA); $L W$ (BC, CELC), Article XXIII: The Marriage of Priests, AAC (1531), I, XI (Gen. 1:28 teaches sexual desire of spouses for one another - the love of one sex for the other is a divine ordinance - this cannot be suspended); LW, 5 (LG), Genesis $29: 12$, Marriage is a godly thing, namely the natural inclination of sex from sex; $L W, 5$ (LG), Genesis 26:8, God's just judgment of the promiscuity and the unspeakable crimes of Sodom in place of the divine institution. 
involved but the absence of the love of God (LW, 2 (LG), Genesis 6:4). The world shuns marriage as the legitimate, divinely instituted union of the male and the female and prefers to indulge in promiscuous relations, which are harmful in more than one way property is squandered, bodies are damaged by serious diseases, God is provoked to inflict horrible punishments, and, worst of all, states and households are destroyed (LW, 3 (LG), Genesis 16:5).48 Luther vividly sketches the benefits of conjugal union in contrast to the evils befalling sexual vice. The estate of marriage redounds to the benefit not alone of the body, property, honour, and soul of an individual, but also to the benefit of whole cities and countries, in that they remain exempt from the plagues imposed by God. The most terrible plagues have befallen lands and people because of fornication. This was the sin cited in the deluge (Gen. 6:1-13), and Sodom and Gomorrah were buried in flames (Gen. 19:1-24). Scripture also cites many other plagues even in the case of holy men such as David (2 Sam. 11-12), Solomon (1 Kings 11:1-13), and Samson (Judg. 16:1-21). We see before our very eyes that God even now sends more new plagues ( $L W, 45: 42$ (CIS (II), EM)). The pagans seek but fail to find in marriage anything beyond a carnal and fleeting sensual pleasure (LW, 45 (CIS (II), EM)). Christian freedom is not given to be used for man's own pleasure and caprice, or to harm, injure, or cause vexation to others, but only for the need and danger of the conscience, so that each may serve the other and benefit him (LW, 46:308 (CIS (III), OMM); LW, 46:309 (CIS (III), OMM)). Luther adds that marital chastity is a constitutive value in society. If the marriage bond is done away with and promiscuous passions are permitted, "the laws and all decency go to ruin with discipline". When these are destroyed, no government remains; only beastliness and savagery are left ( $L W, 3$ (LG) Genesis 19:6). Ultimately conjugal vice is an example of false love. False love is that which seeks its own, as man loves money, and takes women outside of marriage and against God's command (LW, 44:9 (CIS (I), SEM)).

48 Luther contrasts Christian freedom with the licence of the world:

Die ungläubigen mögen tun, was sie wollen, aber christliche Freiheit soll sich richten nach die Liebe, also dass es alles soll zum Dienst des Nächsten sich richten, wo es ohn Not und Fehler des Glaubens und Gewissens geschehen kann. Aber itzt will jedermann die Freiheit suchen, die ihm dienet und nutz ist, gar nichts geachtet wider des Nähesten Nutz und Besserung, so doch St. Paulus sagt: 'Omnia licent, sed non omnia expediunt.' (WA (Br) 4:141, No. 1526, 1525.) 


\section{- Marital dignity as the value of conceiving, rearing and educating the offspring}

Marriage is the constitutive font and origin of human society, therefore matrimony must be held in honour. Marriage should be treated with honour because from it we all originate, because it is a "nursery" not only for the state, but also for the church and the kingdom of Christ - therefore marriage has its own glory ( $L W, 1$ (LG), Genesis 4:2). Luther often alludes to marriage as the "nursery" of human society. It is honourable because it is the source of both the family and the state, and the nursery of the church: "God wanted to leave a nursery of the human race" ( $L W, 2$ (LG), Genesis 9:1 \& LW, 2 (LG), Genesis 6:3). 49 Scripture praises the dignity of marriage at great length. Marriage is to be held in honour, not only because it is the source and origin of the household, state and church, but because they also derive their growth from marriage and the household ( $L W, 4$ (LG), Genesis 24:5).50 Talks about marriage should be conducted in a most respectable manner and love for the offspring should be commanded because it increases the household, the state and the church ( $L W, 4$ (LG), Genesis 25:5). Because of its constitutive role in human society, marriage is not a trifling matter:

... it is the most serious and most important matter in the whole world, because it is the source of human society and of the human race. Life in its entirety has nothing that excels it in worth. Therefore one should discuss it with the utmost piety and on the basis of the weightiest arguments and reasons. For in other circumstances it has been dishonoured enough by concupiscence of the flesh and by lust. (LW, 4, (LG), Genesis 24:5.)

All of mankind has its origin from marriage and domestic arrangements. God Himself is the Author of these offices, they are most excellent and most pleasing exercises of godliness towards God and men. God wants the foetus to be born from the womb and to be suckled and kept warm by the earnest care of mothers that it may be

Elsewhere Luther states that the purpose of marriage is not to have pleasure and to be idle, but to procreate and bring up children, to support a household those who have no love for children are "swine, stocks, and logs unworthy of being called men and women", for they despise the blessing of God, the Creator and author of marriage.

50 Also note $L W, 5$ (LG), Genesis 26:8, Scripture records (Abraham's) marriage for purposes of honouring and showing respect for marriage in which God regards the offspring and chastity as the two adornments of marriage. 
nourished and grow, therefore He has placed milk in the breasts. The Lord of the greatest and least, of kings and slaves, of men and women, is the same; we all have one and the same God, and we are all one in unified worship of God, even if our works and vocations are different ( $L W, 4$ (LG), Genesis 24:5). ${ }^{51}$ Luther extols the virtue of the marital estate by reference to the benefit it has for the whole of society.

\subsubsection{Marital dignity as the value of virtuous love}

Of all the kinds of love, says Luther, marital love is the purest ( $L W$, 44:8 (SEM)). God instituted the pure and honourable form of marital love, but the Antichrist does not regard this love (LW, 35:313 (W\&S (I), POT)). After the fall, marriage became "a hospital for incurables" (LW, 44:394 (CIS (I), SEM)). Marital love excludes all forms of fornication - we are to live chastely in marriage, in body, words, gestures, and heart. That is why God gave to each his wife to love. Each one should look to his own house and neither permit nor counsel fornication, but rather prevent it, because God's Word commands it (1 Cor. 7:2). God demands: "You shall be chaste in words and deeds and keep your wife and love her, and you shall honour your husband" (LW, 51:154 (S (I), SFF)). Luther calls upon marriage partners to cultivate marital love by trusting in God and as much as is possible, preserving harmony (LW, 3 (LG), Genesis 16:7). Marital love is one of the noble virtues of conjugal union (LW, 45:41 (CIS (II), EM)). 52

See $L W$ (4 (LG), Genesis 24:4, The final cause of marriage is not lust and the pleasure of the flesh but marriage serves a twofold purpose: in the first place, to be a remedy against lust; in the second place - and this is more important - to be a source and origin of the human race, in order that offspring may be born and the human race be propagated, or as the jurists say, to replenish the city. But from the holy Scriptures one should add the purpose of bringing up children in the discipline and fear of the Lord, in order that they may be equipped to govern the church and the state; $L W, 6$ (LG), Genesis 37:14, We all have our origin from marriage and domestic arrangements - God Himself is the Author of these offices).

52 To Luther the loss of virtue invariably culminates in moral evil (cf. WA (TR) (Anton Lauterbach, 1538, No. 3982), where Luther adds that the state has an active role to play in fighting moral evil):

\footnotetext{
Also geschahe den zu Sodom, welche auch noch bei Leben Abrahams, des grossen heiligen Erzvaters und Helden, durch welchen sie Gott erlöset hatte von den vier königen, ihren Feinden, Gottes Wolthaten vergassen und verachteten Abraham, der sie den rechten Weg zur Seligkeit lehrete; da ist auch die wahre Religion, Polizei und Disciplin untergangen und die Straf ist bald darauf gefolget.
} 


\subsubsection{Marital dignity as the value of attaining the supreme good}

The highest aim of marriage is not to enjoy sexual union or even the production of offspring, its highest aim is spiritual in nature.53 Although God drives mankind to marriage by means of sensual desire, marriage finds its highest goal in the spiritual sphere (see $L W, 54: 99$ (TT), recorded by Veit Dietrich, No. 566: Good and Evil are used and misused (summer or fall, 1533)). Firstly, marriage is by nature of a kind to teach and compel us to trust in God's hand and grace, and in the same way it forces us to believe; only marriage has a reason for and exercise in faith towards God (LW, 28 (C\&T), 1 Corinthians $7: 8)$. Marriage has been instituted by God, and it drives and helps us along towards the Spirit and faith ( $L W, 28$ (C\&T), 1 Corinthians 7:8). Marriage by nature is of such a kind that it drives, impels, and forces men to the most inward, highest spiritual state, to faith. There is no higher or a more inward state than faith, for faith depends solely on God's Word. Therefore the order of marriage is a heavenly, spiritual, and godly order compared with the religious works ( $L W, 28$ ((C\&T), 1 Corinthians $7: 8)$. The Holy Spirit is instrumental in appreciating the value of the estate of marriage and the household, and therefore all the duties of Christians, such as loving one's wife, rearing one's children, governing one's family, and honouring one's parents, are fruits of the Spirit. The "blind men" do not distinguish between vices and the things that are good creatures of God (LW, 26 (LGS, 1535), Galatians 3:5). Alluding to St. Paul's praises of matrimony, calling it a "divine gift", Luther praises matrimony as the most religious state of all, stating that it is unjust and wrong to refer to certain other estates as "religious" orders while calling marriage a "secular order" - "marriage is the real religious order" (LW, 28 (C\&T), 1 Cor. 7:8). 54

53 Note Luther's letter to Johann Purgott (WA (Br) 5:213, No. 1513, 1529-1530): “... an apostolus Paulus habuerit uxorem, ausklingend in einen Lobpreis der ehe, die Gott eingesetzt habe, die Apostel empfehlen und die Natur ...".

54 Also note Luther's remarks emphasising the higher spiritual goal and aim of marriage ( $L W, 44: 10$ (CIS (I), SEM), Marriage is not only there to produce offspring; marriage should praise and honour God; LW, 21 (SMM), Matthew 5:3, There is no higher social calling in which Christians can exercise their faith in deeds of serving love for their families and neighbours; LW, 45:46 (CIS (II), EM), No estate is better in the sight of God than the estate of marriage; $L W, 2$ (LG), Genesis 23:3, Sexual sins amount to forsaking God - it is not in the first place the integrity of sex and dignity which is involved but the absence of the love of God; $L W, 45: 41$ (CIS (II), EM), The Pagans seek but fail to find in marriage anything beyond a carnal and fleeting sensual pleasure; LW, 28 (C\&T), 1 Corinthians 7:7, Marriage by nature is of such a kind that it drives, impels, and forces men to the most inward, highest spiritual state, to faith; there is nothing higher or more inward than faith; $L W, 3$ (LG), Genesis 18:9, The final cause of 


\section{Conclusion}

The rights pertaining to marriage and conjugal union in Luther's marital ethic are closely intertwined with his moral views on duty and right. Because marriage is a divine institution, the nature and structure of the marital union and the bond bringing marriage into existence cannot be changed at will. Marriage is one of the divine stations and orders established by God to ensure in the world a stable, orderly and peaceful life, that justice may be preserved in all social bonds. God's righteousness is called "natural law" by jurists, and God's righteousness preserves the various stations of life in society - if God had not instituted these stations and did not duly preserve them as his work, no particle of light would last even for a moment. Natural law therefore also aims at preserving marriage as a basic station and order of society. The positive laws of legislators, too, are subject to the tenets of natural law, because "this is the end of all laws" - "all earthly things have been made subject to natural law and reason". Although the duties established by God have almost been done away with, the validity of natural law and its application to marriage has not been changed. Marriage is "a matter of divine right and provides us with a different definition of marriage".

From Luther's implicit distinction between de facto and de jure conjugal union, important perspectives can be gleaned. Firstly, the fullness of marital union common to all human beings, depends upon the benevolent love required from married spouses in attaining the supreme good. Secondly, the fullness of conjugal union proper to the two sexes of the human race aims at the generation of the human race by two persons of different sex endowed with individual

marriage is the glory of God; $L W, 4$ (LG), Genesis 24:44, The dignity of marriage is situated in recognising the glory of God; $L W, 4$ (LG), Genesis 24:4, Marriage must be held in high esteem because it is the source and origin of the household, the state and the church - in the church we seek the glory of God; in the state, peace; and in the household, the rearing of children; LW, 4 (LG), Genesis $24: 44$, Marriage is not merely a sexual union because it has a place among the highest levels of spiritual life, for the loftiest sentiments of married people toward God and man are being cultivated; $L W, 4$ (LG), Genesis 24:4, A marriage is not merely a coition of beasts; LW, 5 (LG), Genesis $26: 8$, The world only sees marriage as nothing else than sexual intercourse, kisses and embraces; $L W, 4$ (LG), Genesis 24:4, The papists do not take into consideration the material, efficient, or final cause of marriage, but regard it to be a kind of copulation; $L W, 4$ (LG), Genesis 22:13, In Holy Scripture the fear of God is the highest form of worship; LW, 5 (LG), Genesis 26:8, Oppose the "swine" who seek only the pleasure of the flesh, oppose the enemies of marriage). 
natural rights. 55 Because marriage is founded in the generation of the human race, two broad categories of duties and rights pertaining to marriage can be discerned, viz. the duties and rights concerning conjugal union as such (indissolubility, unicity, cohabitation, community of goods, etc.), and the duties and rights relative to the order of conjugal union befitting human nature (e.g. sexual union, conjugal debts, sexual intercourse befitting human nature, and conceiving, rearing and educating offspring). In the final instance it can safely be said that the development of Luther's perspectives on the duties and rights involved in conjugal union entails that the right to dignity of marriage is composed of an intricate conglomeration of social duties, which make up the moral-jural dignity of marriage as a social institution.

The rights pertaining to marriage and conjugal love belong to the domain of creation and not to that of redemption. Marriage is rooted in the creative will of God as one of the divine ordinances. Apart from the aims of trust and its sacramental character, God instituted marriage for the propagation of the human race. Through marriage God provided for preserving procreation, and therefore, only through marriage does God permit sexual intercourse. God's calling does not extend to Jews or Christians only, He wants all people to act virtuously. God is not only the God of the Jews, but also the God of the Gentiles. All men through benevolent love are commanded in every law of the Lord, not to serve themselves but their neighbours.

The justice of marriage between man and woman is situated in the fact that conjugal union is a natural right and natural rights are unchangeable, therefore human regulations cannot abolish them. Marriage as natural right cannot be circumvented because the union of man and woman is an ordinance stamped on nature and only God can change it. Because marriage is a creation of divine providence it is a natural right. Marriage as the law of nature cannot be repealed by laws or vows. Non-Christians, too, realise that there is nothing more proper and advantageous than this close relationship

55 For Luther's view that the estate of marriage is subject to natural law in the order of creation, note his remarks ( $L W, 15: 338$ (ESL\&S), Preface):

It would, therefore, be more correct to call this Book of Ecclesiastes the Politics or Economics of Solomon. He does not, indeed, legislate or prescribe laws for the governance of the state or the family. This is taken care of in great detail by the natural law or human reason, to which, according to Genesis 1:28, earthly things have been subjected. This has been, is, and must remain the source, the criterion, and the end of all laws, whether political or domestic. 
of married people - hence they declare that according to natural law a wife is necessary and man and woman should maintain inseparable association until death. The primary truth, says Luther, is that rights of marriage were given by God and not by man.

Reflections on the implications of Luther's appeals for our own country lead us to state that perhaps the time has arrived for the stronger protection of the natural rights of married people, who can make a meaningful difference to the moral deterioration in our society. The time is right to combat the blatant secularism in marriage affairs in our country with a more profound appreciation of what marital life and conjugal union contribute towards the moral integrity of South African society. This would, arguably, also be Luther's advice to Christians in our time, confronted by the moral disintegration we are currently experiencing.

From a wider perspective on society and the moral bonds needed for establishing a common moral-jural framework for harmonious coexistence in society, the implications of Luther's message entail that all societies have moral-jural limits in marriage arrangements. Such marriage arrangements have common moral-jural boundaries oriented towards justice and the promotion of benevolence in society. Aimed at promoting benevolent love in conjugal union and at attaining the ultimate good and virtue in society, the de jure establishment of marriage posits the limits common to all marriages. Furthermore, all institutions of civil society should strive to promote the de facto fullness of conjugal union by supporting marriage as an institution of fundamental importance for providing a "nursery of human society" something our country is direly in need of.

In a broader context Luther's commitment to benevolence in all societal relations contains strong pointers to appreciate the value in the temporal realm of life, that reason illuminated by faith and justice tempered by benevolent love, can cultivate civil responsibilities needed for the moral regeneration of South African society. One need not be a Christian to appreciate the depth of moral degeneration that has ruined inter-individual relations in our country, and the ambit of conjugal deterioration and the width of familial disintegration that has made South African civil society into a moral quagmire of disbanded conjugal relationships and morally deprived children. The urgent need for morally informing law and providing love with an appropriate social form reflecting the commitment of the largest segment of our population to Christianity, must be debated and discoursed as a priority of immanent importance. 


\section{List of references}

ARISTOTLE. 1962. Ethica Nicomacheia. Oxford: Clarendon.

CICERO, M. 1928. De Officiis. Transl. by W. Miller. London: Heinemann.

CICERO, M. 1948. De Re Publica \& De Legibus. Transl. by C.W. Keyes. London: Heinemann.

$\mathrm{DL}$

see CICERO, M. 1948.

DO

see CICERO, M. 1928.

LUTHER, M. 1883-1987. Werke. Kritische gesamtausgabe (78 Bde.). Weimar: Hermann Böhlaus Nachfolger. 56

LUTHER, M. 1999 (c1955). (SP (I)) Luther's works. Vol. 12: Selected Psalms 1 (1532). Ed. by J.J. Pelikan, H.C. Oswald \& H.T. Lehmann. Saint Louis: Concordia Publishing House. 57

LUTHER, M. 1999 (c1956). (SP (II)). Luther's works. Vol. 13: Selected Psalms 2. Ed. by J.J. Pelikan, H.C. Oswald \& H.T. Lehmann. Saint Louis: Concordia Publishing House. 58

LUTHER, M. 1999 (c1956). (SMM): Luther's works. Vol. 21: The Sermon on the Mount and the Magnificat. Ed. by J.J. Pelikan, H.C. Oswald \& H.T. Lehmann. Saint Louis: Concordia Publishing House. 59

LUTHER, M. 1999 (c1957). (SJ (I)). Luther's works. Vol. 22: Sermons on the Gospel of St. John: chapters 1-4 (1514 et seq.). Ed. by J.J. Pelikan, H.C. Oswald \& H.T. Lehmann. Saint Louis: Concordia Publishing House. 60

LUTHER, M. 1999 (c1958). (LG). Luther's works. Vol. 1: Lectures on Genesis: chapters 1-5. Ed. by J.J. Pelikan, H.C. Oswald \& H.T. Lehmann. Saint Louis: Concordia Publishing House.

$56 \quad W A(\mathrm{Br})=$ Luther's letters; $W A(\mathrm{~S})=$ Luther's writings; $W A(\mathrm{P})=$ Luther's sermons; $W A(T R)=$ Luther's table talk.

57 Psalm 2: WA, 40, 193-312 (SL 5), 74-189; Psalm 45: WA, 40, 472-610 (SL 5), 340-471; Psalm 51: WA, 55, 204-250 (SL 5), 188-237; Psalm 26: WA, 17(I), 228-243 (SL 5), 292-307; Psalm 19: WA, 31(I), 580-586 (SL 5), 1332-1339; Psalm 23: WA, 51, 267-295 (SL 5), 1332-1339.

58 Psalm 68 (1521): WA, 8, 4-35 (SL 5) 656-659; Psalm 82 (c. 1530): WA, 31(1), 189-218 (SL 5) 696-731, HE 4, 287-323; Psalm 101 (1534): WA, 51, 200-264 (SL 5) 800-887 (Also note WA (S) 53, 659-678); Psalm 112 (1526): WA, 19, 297-336 (SL 5) 1098-1131; Psalm 90 (1534-1535): WA, 40-3, 476-594 (SL 5) 732-799; Psalm 110 (1535): WA, 41, 79-239 (SL 5) 922-1055; Psalm 111 (1530): WA, 31, 393-426 (SL 5), 1056-1097.

59 Sermon on the Mount (1532): WA, 32, 299-544 (SL 7) 346-677; Magnificat (1521): WA, 7, 538-604 (SL 7) 1372-1445, HE 3, 119-200.

60 Chapters 1 \& 2: WA, 46, 538-789 (SL 7) 1538-1849; Chapters 3 \& 4: WA, 47, 1231, SL 7, 1848-2147. 
LUTHER, M. 1999 (c1959). (W\&S (II)). Luther's works. Vol. 36: Word and sacrament 2. Ed. by J.J. Pelikan, H.C. Oswald \& H.T. Lehmann. Saint Louis: Fortress. 61

LUTHER, M. 1999 (c1959). (S (I)). Luther's works. Vol. 51: Sermons 1. Ed. by J.J. Pelikan, H.C. Oswald \& H.T. Lehmann. Saint Louis: Fortress. 62

LUTHER, M. 1999 (c1960). (CR (IV)). Luther's works. Vol. 34: Career of the reformer 4. Ed. by J.J. Pelikan, H.C. Oswald \& H.T. Lehmann. Saint Louis: Fortress. 63

LUTHER, M. 1999 (c1960). (LD). Luther's works. Vol. 9: Lectures on Deuteronomy. Ed. by J.J. Pelikan, H.C. Oswald \& H.T. Lehmann. Saint Louis: Concordia Publishing House.

LUTHER, M. 1999 (c1960). (LG). Luther's works. Vol. 2: Lectures on Genesis: chapters 6-14 (1535/1536). Ed. by J.J. Pelikan, H.C. Oswald \& H.J. Lehmann. Saint Louis: Concordia Publishing House. (WA, 42, 264-549 (SL 1) 486-921). 64

LUTHER, M. 1999 (c1960). (W\&S (I)). Luther's works. Vol. 35: Word and sacrament 1. Ed. by J.J. Pelikan, H.C. Oswald \& H.T. Lehmann. Saint Louis: Fortress. 65

LUTHER, M. 1999 (c1961). (LG). Luther's works. Vol. 3: Lectures on Genesis: chapters 15-20 (c. 1539). Ed. by J.J. Pelikan, H.C. Oswald \& H.T. Lehmann. Saint Louis: Concordia Publishing House. (WA, 42, 550-43, 137 (SL 1) 920-1369).

LUTHER, M. 1999 (c1961). (W\&S (III)). Luther's works. Vol. 37: Word and sacrament 3. Ed. by J.J. Pelikan, H.C. Oswald \& H.T. Lehmann. Saint Louis: Fortress. 66

LUTHER, M. 1999 (c1962). (CS (II)). Luther's works. Vol. 45: The Christian in society 2. Ed. by J.J. Pelikan, H.C. Oswald \& H.T. Lehmann. Saint Louis: Fortress. 67

61 (SBBC) The Sacrament of the body and blood of Christ - against the fanatics (1526), 328-360.

62 (SML) Sermon on the marriage of Sigismund von Lindenau (1545): WA, 49, 797-805) This sermon alludes to Hebrews 14:4: "Let marriage be held in honour among all, and let the marriage bed be undefiled; for God will judge the immoral and adulterous."; (SFF) Sermon on the fourth and fifth commandments (1528): WA, 30-1, 1-122.

63 (EGA) Exhortation to All clergy assembled at Augsburg (1530), 3-61; (TF\&L) Theses concerning faith and law (1535), 104-133.

64 Corresponding references to the standard edition of Weimar (WA) (1883-1987) are provided after the bibliographical information of specific volumes of Luther's Works where applicable. In some instances the corresponding references to the St. Louis edition (SE) of Luther's Works are also given.

65 (POT) Prefaces to the Old Testament, 235-332; (PA) Prefaces to the Apocrypha, 335-353; (PNT) Prefaces to the New Testament, 355-410.

66 (CCCS) Confession concerning Christ's Supper (1528), 151-371. 
LUTHER, M. 1999 (c1963). (LGS (I)). Luther's works. Vol. 26: Lectures on Galatians (1535): chapters 1-4. Ed. by J.J. Pelikan, H.C. Oswald \& H.T. Lehmann. Saint Louis: Concordia Publishing House.

LUTHER, M. 1999 (c1964). (LG). Luther's works. Vol. 4: Lectures on Genesis: chapters 21-25 (1539). Ed. by J.J. Pelikan, H.C. Oswald \& H.T. Lehmann. Saint Louis: Concordia Publishing House. (WA, 43, 137-430 (SL 1) 13681765).

LUTHER, M. 1999 (c1965). (LG). Luther's works. Vol. 7: Lectures on Genesis: chapters 38-44 (c. 1543). Ed. by J.J. Pelikan, H.C. Oswald \& H.T. Lehmann. Saint Louis: Concordia Publishing House. (WA, 44, 304-581 (SL 2) 1158-1655).

LUTHER, M. 1999 (c1966). (C\&M (III)). Luther's works. Vol. 41: Church and ministry 3. Ed. by J.J. Pelikan, H.C. Oswald \& H.T. Lehmann. Saint Louis: Fortress. 68

LUTHER, M. 1999 (c1966). (CS (I)). Luther's works. Vol. 44: The Christian in society 1. Ed. by J.J. Pelikan, H.C. Oswald \& H.T. Lehmann. Saint Louis: Fortress. 69

LUTHER, M. 1999 (c1966). (LG). Luther's works. Vol. 8: Lectures on Genesis: chapters 45-50 (1545). Ed. by J.J. Pelikan, H.C. Oswald \& H.T. Lehmann. Saint Louis: Concordia Publishing House.

LUTHER, M. 1999 (c1967). (CS (III)). Luther's works. Vol. 46: The Christian in society 3. Ed. by J.J. Pelikan, H.C. Oswald \& H.T. Lehmann. Saint Louis: Fortress. 70

LUTHER, M. 1999 (c1967). (TT). Luther's works. Vol. 54: Table talk. Ed. by J.J. Pelikan, H.C. Oswald \& H.T. Lehmann. Saint Louis: Fortress. 71

LUTHER, M. 1999 (c1968). (LG). Luther's works. Vol. 5: Lectures on Genesis: chapters 26-30 (1541). Ed. by J.J. Pelikan, H.C. Oswald \& H.T. Lehmann. Saint Louis: Concordia Publishing House. (WA, 43, 431-695 (SL 2) 122609).

67 (EM) The estate of marriage (1522), 11-49 (WA, 10(2), 275-304); (PCM) That parents should neither compel nor hinder the marriage of their children and that children should not become engaged without their parents' consent (1524), 379393 (WA, 15, (155) 163-169).

68 (CC) On the councils of the church (1538), 3-177 (WA, 50, 509-653).

69 (SEM) A sermon on the estate of marriage (1519), 3-15 (WA, 2, (162) 166-171); (CNGN) To the Christian nobility of the German nation concerning the reform of the Christian estate (1520), 114-219.

70 (SBS) Whether soldiers, too, can be saved (1526), 84-137; (WAT) On war against the Turk (1529), 154-205; (OMM) On marriage matters (1530), 257-320 (WA, 30-3, (198), 205-248).

71 Table talk collected by Anthony Lauterbach and Jerome Weller: In praise of women (1537) (selections from WA, TT \& WA, 48, 365-719 \& Table talk collected by Arnold Cordatus: No. 2867b: Annoyances and blessings in marriage, January 2, 1533). 
LUTHER, M. 1999 (c1970). (C\&M (II)). Luther's works. Vol. 40: Church and ministry 2. Ed. by J.J. Pelikan, H.C. Oswald \& H.T. Lehmann. Saint Louis: Fortress. 72

LUTHER, M. 1999 (c1970). (LG). Luther's works. Vol. 6: Lectures on Genesis: chapters 31-37 (1542 et seq.). Ed. by J.J. Pelikan, H.C. Oswald \& H.T. Lehmann. Saint Louis: Concordia Publishing House. (WA, 44, 1-304, (SL 2) 608-1159).

LUTHER, M. 1999 (c1972). (ESL\&S). Luther's works. Vol. 15: Ecclesiastes, Song of Solomon, Last Words of David, 2 Samuel 23:1-7. Ed. by J.J. Pelikan, H.C. Oswald \& H.T. Lehmann. Saint Louis: Concordia Publishing House. 73

LUTHER, M. 1999 (c1972). (LI (II)). Luther's works. Vol. 17: Lectures on Isaiah: chapters 40-66. Ed. by J.J. Pelikan, H.C. Oswald \& H.T Lehmann. Saint Louis: Concordia Publishing House.

LUTHER, M. 1999 (c1972). (LR). Luther's works. Vol. 25: Lectures on Romans (1535). Ed. by J.J. Pelikan, H.C. Oswald \& H.T. Lehmann. Saint Louis: Concordia Publishing House.

LUTHER, M. 1999 (c1973). (C\&T). Luther's works. Vol. 28: 1 Corinthians 15, Lectures on 1 Timothy. Ed. by J.J. Pelikan, H.C. Oswald \& H.T. Lehmann. Saint Louis: Concordia Publishing House. 74

LUTHER, M. 1999 (c1975). (LMP (I)). Luther's works. Vol. 18: Minor Prophets 1: Hosea-Malachi. Ed. by J.J. Pelikan, H.C. Oswald \& H.T. Lehmann. Saint Louis: Concordia Publishing House.

LUTHER, M. 1999 (c1976). (FLP (II)). Luther's works. Vol. 11: First lectures on the Psalms 2: Psalms 76-126 (c. 1515). 75 Ed. by J.J. Pelikan, H.C. Oswald \& H.T. Lehman. Saint Louis: Concordia Publishing House.

LW

see LUTHER, M. 1999

MAURER, W. 1970. Luthers Lehre von den drei Hierarchien und ihr mittelalterlicher Hintergrund. München: Verlag der Bayerischen Akademie der Wissenschaften. (Philosophisch-Historische Klasse: Sitzungsberichte, 4.)

RAATH, A.W.G. 2007a. The justness of love: the essence and status of justice in Luther's theology. Studia historiae ecclesisticae, 32(1):335-354.

RAATH, A.W.G. 2007b. Personhood, human nature and the foundations of fundamental rights in Martin Luther's theology, Nederduitse Gereformeerde teologiese tydskrif, 48(1 \& 2):169-187.

72 (IPP) Instructions for the visitors of parish pastors in electoral Saxony (1528), 262-320; (TK) The Keyes (1530), 320-377.

73 Notes on Ecclesiastes (1526): WA, 20, 7-203 (SL 5) 1372-1579; Lectures on the Song of Solomon (1530-1531): WA, 31-2, 586-769 (SL 5) 1580-1659); Treatise on the Last Words of David (1543): WA, 54, 28-100 (SL 3) 1880-1973.

741 Corinthians 7 (1523); 1 Corinthians 15 (1534); Lectures on Timothy (15271528).

75 Psalm 119 (c. 1515). 
RAATH, A.W.G. 2007c. Human personhood and social benevolence reformational reflections on the right to human dignity, Koers, 72(2):1-32.

TAPPERT, T.G.. ed. 2000 (c1959). (AC). The Augsburg Confession. Transl. from the Latin. Philadelphia: Fortress. (Luther's works (LW).)

TAPPERT, T.G., ed. 2000 (c1959). (BC: CELC). The book of concord: the confessions of the Evangelical Lutheran Church. Philadelphia: Fortress. $\mathbf{7 6}$

WA

see LUTHER, M. 1883-1987.

\section{Key concepts:}

conjugal rights

Luther, M.

marriage

\section{Kernbegrippe:}

huwelik

huweliksregte

Luther, M.

76 Luther's works (LW). ((CF) Augsburg Confession (1530); (AAC) Apology of the Augsburg Confession (1-1,14) (1531). (At first regarded as a private publication of Melanchthon, it became the official confession of faith when it was signed, along with the Augsburg Confession in Smalcald in 1537.); (SC) The small catechism (1529) (1-8, 15); (LC) The large catechism (1529) (1-6, 35). 
